\title{
見学記
}

\section{(株)安川電機モートマンセンタ・北九州学術研究都市 見学記}

2007 年 8 月 3 日(金)に, (株) 安川電機モートマンセンタ (北九州市八幡西区) , 及び北九州学術研究都市 (北九州市 若松区）の見学会が実施されました。

\section{見学に当たりましては}

13:00〜 14:30 （株）安川電機モートマンセンタ モートマンステーション

14:30〜 15:10 (バス移動)

15:10 16:40 北九州学術研究都市

環境エネルギーセンター 共同研究開発センター 情報技術高度化センター というスケジュールで行いました。

安川電機では, 会社概要・工場等のご説明を頂いた後, 2 班に分かれて工場見学を行いました。ロボットがロボッ トを作る工場として世界で最初に操業を開始された CIM 化 ロボット工場のモートマンセンタと, 溶接ロボットや液晶 ガラス基板搬送用ロボットなどの中・大型ロボットの生産 を行っているモートマンステーションを見学させていただ きました。見学後に質疑応答の時間をとっていただきまし たが，参加頂いた皆さんからの熱心な質問に，やや時間を 超過して対応いただきました。

その後, バスで翌日の第 169 回定例研究会の会場でもあ る北九州学術研究都市へ移動しました。北九州学術研究都 市は, 九州工業大学, 北九州市立大学, 早稲田大学, およ び共同利用施設が集まっており, 今回は共同利用施設の環 境エネルギーセンター，共同研究開発センター，情報技術 高度化センターを見学させていただきました。環境エネル ギーセンターでは, リン酸型燃料電池 $(200 \mathrm{~kW})$ とガスエン ジン $(160 \mathrm{~kW})$ のコジェネシステム, 排熱利用設備などを見 学しました。ここで発電された電力や, 温水は域内の施設 に供給されています。また, 学研都市内の排水や雨水は共 同溝を経由して環境エネルギーセンターへ集められ，排水 処理設備でろ過されて各施設で再利用されており，これら の設備を見学しました。共同研究開発センターでは, IC や MEMS を試作する製造装置が外部に開放されおり，これら の設備を見学しました。情報技術高度化センターでは, シ
ステム LSI の設計環境や, 半導体チップ開発等の技術講座 が開講されている研修室, 評価試験設備などを見学しまし た。

今回は, 見学会の前日から当日の未明にかけて台風 5 号 の直撃を受け見学会の開催が危ぶまれましたが，幸いにし て, 台風も直前に通り過ぎ，28 名の参加で無事見学会を開 催することができました。ただ四国方面からご参加の方々 には瀬戸内海を渡る交通手段がストップして見学会にご参 加頂けずご迷惑をおかけいたしましたこと, お詫び申し上 げます。

また，安川電機の末松様はじめ，見学案内いただきまし た関係各位の皆様に厚く感謝いたします。

（文責 : 江口政樹・シャープ）

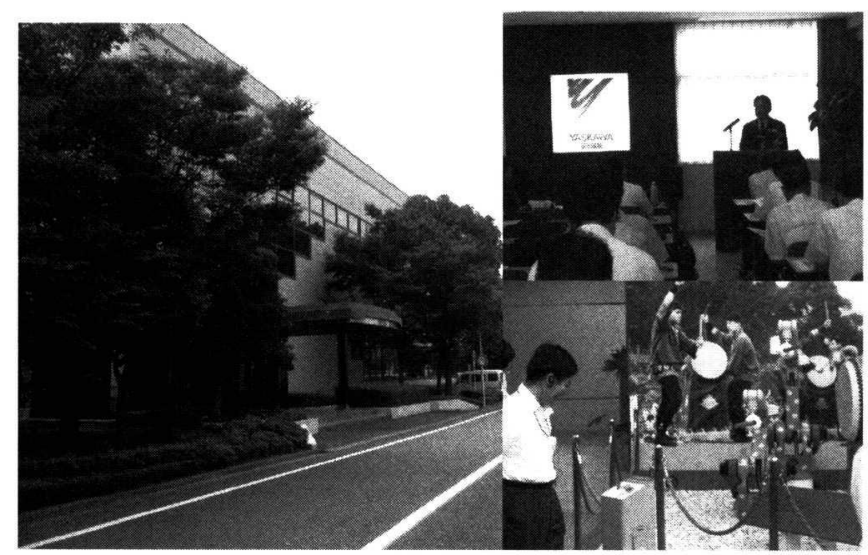

写真 1 （株）安川電機での見学風景

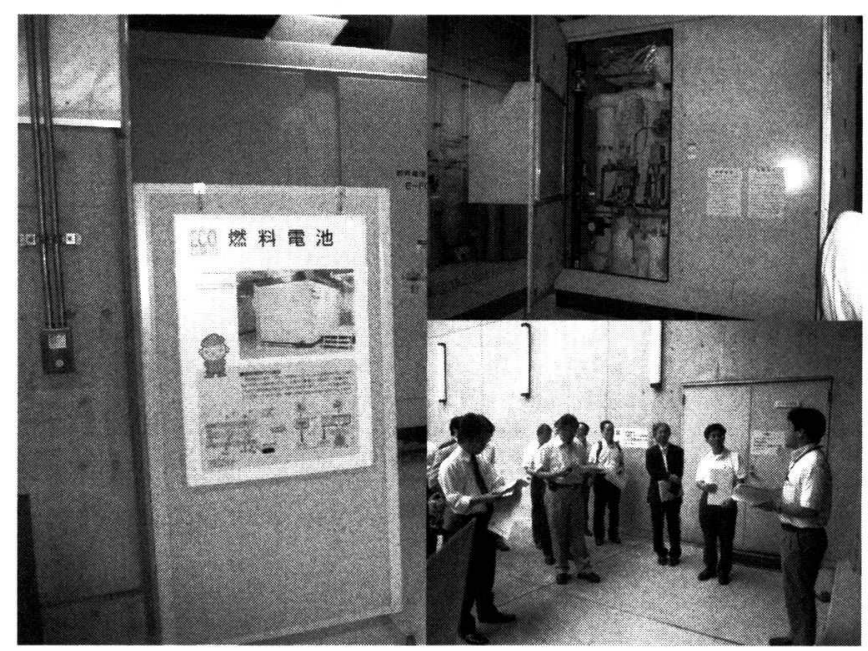

写真 2 環境エネルギーセンターでの見学風景 